\title{
THE UPTAKE OF HEXOSES BY PRE-IMPLANTATION MOUSE EMBRYOS IN VITRO
}

\author{
R. G. WALES* AND R. L. BRINSTER \\ King Ranch Laboratory of Reproductive Physiology, School of Veterinary Medicine, \\ University of Pennsylvania, Philadelphia, Pa, U.S.A. \\ (Received 10th April 1967, revised 29th June 1967)
}

\begin{abstract}
Summary. The accumulation of substrate carbon by mouse embryos was measured following incubation in $\mathrm{U}^{14} \mathrm{C}$-glucose. Following a $30-$ min incubation period $273 \times 10^{-14}$ and $301 \times 10^{-14} \mathrm{~g}$ atoms of substrate carbon per embryo were found in 2- and 8-cell embryos respectively. By comparison, the figures for unfertilized and fertilized ova were $14 \times 10^{-14}$ and $45 \times 10^{-14} \mathrm{~g}$ atoms of substrate carbon.

The intracellular concentration of substrate carbon was timedependent in both 2- and 8-cell embryos. After an 80-min incubation, substrate carbon in the 8-cell embryo was almost double that in the 2-cell embryo. Accumulation did not occur during incubations at $5^{\circ} \mathrm{C}$ and there was competition between glucose and galactose for uptake. The results are discussed in relation to the energy requirements of the developing zygote.
\end{abstract}

\section{INTRODUCTION}

During development of in-vitro techniques for the cultivation of mouse embryos at the pre-implantation stages of development, it was found that the late 2-cell embryo would not develop to the blastocyst when glucose was the sole energy source (Brinster, 1965a). On the other hand, 8-cell embryos would continue development when this substrate was provided (Brinster \& Thomson, 1966). Recent studies using L-malate (Wales \& Biggers, 1968) have indicated that the cell membrane undergoes a change in permeability to this substrate between the first and third cleavage divisions. This raises the question as to whether a similar change in permeability to glucose occurs at this time and is responsible for the difference in the ability of glucose to support development at these two stages.

In an attempt to throw light on this problem, the intracellular accumulation of glucose carbon has been studied at various stages in development. Some studies on the accumulation of galactose are also included.

* Present address: Department of Veterinary Physiology, University of Sydney, Sydney, N.S.W., Australia. 


\section{MATERIALS AND METHODS}

Mouse embryos were obtained from random-bred Swiss mice which had been superovulated by an intraperitoneal injection of 10 i.u. of serum gonadotrophin (Gestyl, Organon), followed $48 \mathrm{hr}$ later by an intraperitoneal injection of $10 \mathrm{i}$.u. of chorionic gonadotrophin (Pregnyl, Organon) (Brinster, 1963). Successive developmental stages of the embryos were removed from the Fallopian tubes of mice at specific times after ovulation. The cumulus cells which surrounded unfertilized ova and single-cell embryos were removed by incubation in hyaluronidase solution (Brinster, 1965b). The basic medium used in the study and the method of washing the embryos free of substrate before incubation have been described previously (Wales \& Biggers, 1968). For the studies of the uptake of substrates, incubations were carried out in tissue culture dishes containing a small drop of radio-active medium in $10 \mathrm{ml}$ of light paraffin oil. In the first experiments, 200 to 3002 -cell embryos and eighty to 1508 -cell embryos were used for each treatment, but in later experiments fifty embryos/ treatment were used for these stages and 150/treatment for 1-cell embryos. Incubations to study the production of carbon dioxide were set up in small test tubes as previously described (Brinster, 1967). For these experiments 300 to 400 2-cell embryos and 100 to 150 8-cell embryos were used.

The U- ${ }^{14} \mathrm{C}$-glucose (Nuclear Chicago Corp.) was diluted with basic diluent to give a concentration of $5.6 \mu \mathrm{mole} / \mathrm{ml}$ and a specific activity of $2.9 \mu \mathrm{c} / \mu \mathrm{mole}$. For the experiment where a low concentration of glucose was used, the above solution was further diluted with basic, substrate-free medium to the desired concentration. The $1{ }^{14} \mathrm{C}$-galactose (Nuclear Chicago Corp.) was used at a concentration of $4.5 \mu \mathrm{mole} / \mathrm{ml}$ and a specific activity of $3.4 \mu \mathrm{c} / \mu \mathrm{mole}$.

To measure the intracellular accumulation of substrate carbon, embryos, at the completion of incubation in the radio-active medium, were collected free of incubation medium and prepared for radio-active assay by liquid scintillation techniques as previously described (Wales \& Biggers, 1968). Incubations at $5^{\circ} \mathrm{C}$ were carried out in a refrigerated room. After collection, the embryos were cooled to $5^{\circ} \mathrm{C}$ over $30 \mathrm{~min}$ in a diluent containing lactate $(25 \mathrm{~mm})$ and pyruvate $(0.25 \mathrm{~mm})$. They were then washed free of substrate at $5^{\circ} \mathrm{C}$ before incubation in the radio-active medium.

Samples of medium were taken for radio-assay at the completion of all incubations in order to determine the actual concentration of substrate present during the incubation period. These concentrations are given in the tables. The accumulation of substrate carbon was then calculated from the counts in the embryos and the specific activity of the substrate in the incubation medium. Where necessary, the data of Lewis \& Wright (1935) were used as an estimate of the volume of the vitellus, to calculate the concentration of isotope in the embryo.

The method used to measure the production of carbon dioxide has been described previously (Brinster, 1967). After a 4-hr incubation, samples were acidified with $0 \cdot 2 \mathrm{~N}-\mathrm{H}_{2} \mathrm{SO}_{4}$ and the evolved carbon dioxide absorbed with $1 \mathrm{ml}$ of 1 м $p$-(diisobutyl-cresoxyethoxyethyl)dimethyl benzyl ammonium hydroxide (hyamine hydroxide, Packard Instrument Company). The radio-activity was then assayed by liquid scintillation techniques. 


\section{RESULTS}

The overall results for the accumulation of substrate carbon by 2- and 8-cell mouse embryos incubated in the presence of glucose $(4.8 \mathrm{~mm})$ are given in Table 1. After a 30 -min incubation, $273 \times 10^{-14} \mathrm{~g}$ atoms of substrate carbon

\section{TABLE 1}

ACGUMULATION OF SUBSTRATE CARBON BY MOUSE EMBRYOS DURING A 30-MIN INGUBATION IN A DILUENT CONTAINING $4 \cdot 8 \mathrm{mM}$ GLUCOSE AS SOLE ENERGY SOURCE

\begin{tabular}{c|c|c}
\hline $\begin{array}{c}\text { Stage of } \\
\text { development }\end{array}$ & $\begin{array}{c}\text { No. of } \\
\text { observations }\end{array}$ & $\begin{array}{c}\text { Substrate carbon accumulated } \\
\left(\mathrm{g} \text { atoms } \times 10^{-14} / \text { embryo }\right)\end{array}$ \\
\cline { 2 - 3 } 2-cell & 9 & $273 \pm 10$ \\
8-cell & 12 & $301 \pm 9$ \\
\hline
\end{tabular}

Mean values \pm standard errors of the means are given.

accumulated in 2-cell embryos, while in 8-cell embryos, $301 \times 10^{-14} \mathrm{~g}$ atoms were found. The difference between 2- and 8-cell embryos was just significant $\left(t_{19}=2 \cdot 1, P=0 \cdot 05\right)$. By comparison the amount of substrate carbon found in 1-cell embryos under similar conditions (Table 2) was low although not as

TABLE 2

UPTAKE OF GLUCOSE ( $3.8 \mathrm{mM}$ ) BY UNFERTILIZED AND FERTILIZED MOUSE OVA DURING A 30-MIN INCUBATION IN THE PRESENCE OR ABSENCE OF LACTATE ( $5 \mathrm{mM}$ ) AND PYRUVATE $(0.05 \mathrm{~mm})$

\begin{tabular}{l|c|c|c}
\hline \multirow{2}{*}{$\begin{array}{c}\text { Stage of } \\
\text { development }\end{array}$} & $\begin{array}{c}\text { Lactate } \\
\text { pyruvate }\end{array}$ & \multicolumn{2}{|c}{$\begin{array}{c}\text { Glucose carbon accumulated } \\
\left(\mathrm{g} \text { atoms } \times 10^{\mathbf{1 4}} / \text { embryo }\right)\end{array}$} \\
\cline { 2 - 4 } & & Rep 1 & Rep 2 \\
\hline Unfertilized & - & 14 & 13 \\
Fertilized & + & 13 & 15 \\
& - & 46 & 51 \\
& + & 40 & 44 \\
\hline
\end{tabular}

low as that found in unfertilized ova. The addition of low levels of lactate and pyruvate to the incubation medium as a readily available alternative energy source did not increase the accumulation of glucose carbon by either fertilized or unfertilized ova.

The effect of varying conditions on the intra-cellular levels of glucose carbon in 2- and 8-cell embryos is shown in Tables 3, 4 and 5. A change in the incubation temperature from $37^{\circ} \mathrm{C}$ to $5^{\circ} \mathrm{C}$ almost completely eliminated any uptake of substrate carbon at both stages of development (Table 3). In the second experiment (Table 4), a glucose concentration of $0.5 \mathrm{~mm}$, instead of $5 \mathrm{~mm}$, resulted in a fall in the intracellular level of glucose carbon to $40 \%$ of that found with the higher concentration. However, with $0.5 \mathrm{~mm}$ glucose, the concentration of substrate carbon in the cell was 2.5 times that in the medium. 
TABLE 3

GOMPARISON OF INGUBATION AT $37^{\circ} \mathrm{C}$ AND $5^{\circ} \mathrm{G}$ FOR 30 MIN ON THE AGGUMULATION OF SUBSTRATE CARBON BY MOUSE EMBRYOS IN A DILUENT CONTAINING $4.9 \mathrm{mM}$ GLUCOSE

\begin{tabular}{c|c|c|c}
\hline $\begin{array}{c}\text { Stage of } \\
\text { development }\end{array}$ & $\begin{array}{c}\text { Temperature } \\
\text { of } \\
\text { incubation } \\
\left({ }^{\circ} \mathrm{C}\right)\end{array}$ & \multicolumn{2}{|c|}{$\begin{array}{c}\text { Substrate carbon accumulated } \\
\left(\mathrm{g} \text { atoms } \times 10^{-14} / \mathrm{emb} \text { bo }\right)\end{array}$} \\
\cline { 2 - 3 } & 37 & $\operatorname{Rep~} 1$ & Rep 2 \\
\hline 2-cell & 5 & 165 & 178 \\
& 37 & 4 & 2 \\
8-cell & 5 & 297 & 311 \\
& & 6 & 9 \\
\hline
\end{tabular}

By contrast, substrate carbon concentration was lower in the cell than in the medium when $5 \mathrm{~mm}$ glucose was added to the incubation medium.

A third experiment was carried out to study the effects of varying the time of

TABLE 4

EFFECT OF A GHANGE IN GLUCOSE CONCENTRATION ON THE ACGUMULATION OF SUBSTRATE CARBON BY MOUSE EMBRYOS

\begin{tabular}{|c|c|c|c|}
\hline \multirow{2}{*}{$\begin{array}{c}\text { Stage } \\
\text { of } \\
\text { development }\end{array}$} & \multirow{2}{*}{$\begin{array}{l}\text { Glucose } \\
\text { concentration } \\
(m M)\end{array}$} & \multicolumn{2}{|c|}{ Substrate carbon accumulated } \\
\hline & & $\begin{array}{c}\text { (i) } \\
\text { gatoms } \times \\
10^{-14} / \text { embryo }\end{array}$ & $\begin{array}{c}\text { (ii) } \\
\mu g \\
\text { atoms } / m l\end{array}$ \\
\hline 2-cell & $\begin{array}{l}5.0 \\
0.5\end{array}$ & $\begin{array}{l}261 \\
111\end{array}$ & $\begin{array}{r}17 \\
7\end{array}$ \\
\hline 8-cell & $\begin{array}{l}4.7 \\
0.5\end{array}$ & $\begin{array}{l}327 \\
126\end{array}$ & $\begin{array}{r}24 \\
9\end{array}$ \\
\hline
\end{tabular}

Mean values for two replicates are given.

incubation (Table 5). For 2-cell embryos, aliquots of two collections of embryos were incubated 3, 9, 27 and $81 \mathrm{~min}$. In the case of 8-cell embryos, insufficient numbers of embryos were collected for all times to be studied at once and a

TABLE 5

ACCUMULATION OF SUBSTRATE GARBON DURING VARYING PERIODS OF INCUBATION IN $5 \cdot 1 \mathrm{mM}$ GLUCOSE

\begin{tabular}{|c|c|c|c|c|c|c|}
\hline \multirow{3}{*}{$\begin{array}{c}\text { Incubation } \\
\text { time } \\
(\text { min })\end{array}$} & \multicolumn{6}{|c|}{$\begin{array}{c}\text { Substrate carbon accumulated } \\
\left(\mathrm{g} \text { atoms } \times 10^{-14} / \text { embryo }\right)\end{array}$} \\
\hline & \multicolumn{2}{|c|}{ 2-cell } & \multicolumn{4}{|c|}{ 8-cell } \\
\hline & $\operatorname{Rep} 1$ & $R_{e p} 2$ & $R e p$ & $\begin{array}{l}1 \\
\operatorname{Rep} 2\end{array}$ & $\operatorname{Rep}$ & $\stackrel{2}{\operatorname{Rep} 2}$ \\
\hline $\begin{array}{r}3 \\
9 \\
27 \\
81\end{array}$ & $\begin{array}{r}53 \\
137 \\
248 \\
286\end{array}$ & $\begin{array}{r}60 \\
122 \\
248 \\
393\end{array}$ & $\begin{array}{r}68 \\
172 \\
319 \\
-\end{array}$ & $\begin{array}{r}60 \\
158 \\
281 \\
-\end{array}$ & $\begin{array}{r}- \\
245 \\
519\end{array}$ & $\begin{array}{c}- \\
\overline{336} \\
615\end{array}$ \\
\hline
\end{tabular}


complementary experiment comparing 27 and $81 \mathrm{~min}$ was carried out separately (see Table 5). Substrate carbon accumulated rapidly in 2-cell embryos during the first 9 min of incubation. Thereafter, the rate of its accumulation decreased. Its concentration doubled during the next $18 \mathrm{~min}$ and the levels at $81 \mathrm{~min}$ were only $40 \%$ above those at $27 \mathrm{~min}$. At all times, there was more substrate carbon accumulation in 8-cell embryos than in 2-cell embryos, and the difference became greater as the time of incubation was increased. This was due to the fact that the rate of accumulation of substrate carbon in 8cell embryos did not fall off as rapidly with time and the levels doubled between 27 and $81 \mathrm{~min}$.

\section{TABLE 6}

METABOLISM OF HEXOSE CARBON BY MOUSE EMBRYOS INCUBATED in a Diluent containing $3.6 \mathrm{~mm} 1-^{14} \mathrm{C}$-galactose

\begin{tabular}{|c|c|c|c|c|}
\hline \multirow{2}{*}{$\begin{array}{c}\text { Stage } \\
\text { of } \\
\text { development }\end{array}$} & \multicolumn{2}{|c|}{$\begin{array}{l}\text { Carbon one of galactose } \\
\text { accumulated in } 30 \mathrm{~min}\end{array}$} & \multicolumn{2}{|c|}{$\begin{array}{l}\mathrm{CO}_{2} \text { produced from carbon one } \\
\text { during 4-hr incubation }\end{array}$} \\
\hline & $\begin{array}{c}\text { No. of } \\
\text { observations }\end{array}$ & $\begin{array}{c}g \text { atoms } \times 10^{-14} / \\
e m b r y o\end{array}$ & $\begin{array}{c}\text { No. of } \\
\text { observations }\end{array}$ & $\begin{array}{c}\text { moles } \times 10^{-14} / \\
\text { embryo }\end{array}$ \\
\hline $\begin{array}{l}\text { 2-cell } \\
\text { 8-cell }\end{array}$ & $\begin{array}{l}4 \\
4\end{array}$ & $\begin{array}{l}41 \cdot 1 \pm 1 \cdot 9 \\
45 \cdot 5 \pm 1 \cdot 4\end{array}$ & $\begin{array}{l}3 \\
3\end{array}$ & $\begin{array}{l}21 \cdot 3 \pm 18 \cdot 0 \\
89 \cdot 7 \pm 2 \cdot 2\end{array}$ \\
\hline
\end{tabular}

Mean values \pm standard errors of the means are given.

In the final experiments, the uptake and utilization of $1{ }^{14} \mathrm{C}$-galactose by mouse embryos was investigated. The accumulation of substrate carbon and the production of carbon dioxide from carbon position one of galactose are shown in Table 6 . The accumulation of carbon from position one of galactose

\section{TABLE 7}

UPtake OF $1{ }^{14} \mathrm{C}$-Galactose $(3.7 \mathrm{mM})$ BY MOUSE EMBRYOS DURING 30-MIN INCUBATION IN THE PRESENCE OR ABSENCE OF LACTATE ( $5 \mathrm{mM}$ ) PLUS PYRUVATE (0.05 mM)

\begin{tabular}{c|c|c|c}
\hline $\begin{array}{c}\text { Stage of } \\
\text { development }\end{array}$ & $\begin{array}{c}\text { Lactate }+ \\
\text { pyruvate }\end{array}$ & $\begin{array}{c}\text { Carbon one of galactose accumulated } \\
\left(\mathrm{g} \text { atoms } \times 10^{-14} / \mathrm{embryo}\right)\end{array}$ \\
\cline { 2 - 3 } 2-cell & - & Rep 1 & Rep 2 \\
\hline 8-cell & + & 41 & 43 \\
& - & 46 & 41 \\
& + & 52 & 48 \\
\hline
\end{tabular}

was one-sixth the total accumulation of carbon from U- ${ }^{14} \mathrm{C}$-glucose. The levels in 8-cell embryos showed a tendency to be higher but the difference was not significant. On the other hand, the production of carbon dioxide by 8-cell embryos was higher than that from the 2-cell stage. In a further experiment (Table 7), the addition of low levels of lactate $(5 \mathrm{~mm})$ and pyruvate $(0.05 \mathrm{~mm})$ to the incubation medium did not significantly affect the accumulation of carbon one of galactose in either 2- or 8-cell embryos. 
The effect of a combination of glucose and galactose on their respective accumulation was also studied. For each sample of embryos collected, equal numbers of embryos were transferred to four droplets of medium containing, respectively, radio-active glucose alone, radio-active glucose plus non-radioactive galactose, radio-active galactose alone and radio-active galactose plus non-radio-active glucose. By assay of the radio-activity incorporated into the

TABLE 8

AGGUMULATION OF HEXOSE GARBON BY MOUSE EMBRYOS INCUBATED 30 MIN IN A DILUENT GONTAINING GLUGOSE $(4.8 \mathrm{mM})$ OR GALACTOSE $(4 \cdot 0 \mathrm{mM})$ ALONE AND IN GOMBINATION

\begin{tabular}{c|cc|cc}
\hline \multirow{2}{*}{$\begin{array}{c}\text { Stage of } \\
\text { development }\end{array}$} & \multicolumn{2}{|c|}{$\begin{array}{c}\text { Total glucose carbon } \\
\text { accumulated }\end{array}$} & \multicolumn{2}{c}{$\begin{array}{c}\text { Carbon one of } \\
\text { galactose accumulated }\end{array}$} \\
\cline { 2 - 3 } & - galactose & + galactose & - glucose & + glucose \\
\hline 2-cell & 250 & 230 & 39 & $19^{* *}$ \\
8-cell & 285 & $208^{* *}$ & 44 & $22^{* *}$ \\
\hline
\end{tabular}

Values are expressed as $g$ atoms $\times 10^{-14} / \mathrm{embryo}$ and are the means of two replicates.

** Significant effect of combination on carbon accumulation, $P<0 \cdot 01$.

embryos in each droplet, the accumulation of substrate carbon from both glucose and galactose, alone or in combination, could be calculated. The results for two replicates at each stage of development (Table 8) showed that the addition of galactose decreased the accumulation of glucose carbon slightly. On the other hand, the intracellular level of galactose carbon was halved by the addition of glucose to the incubation medium.

\section{DISCUSSION}

In these studies a great change in the accumulation of substrate carbon from glucose occurred about the time of fertilization and first cleavage, but after this time there was only a slight change in substrate accumulation. In other studies, it has been found that carbon dioxide production from glucose continues to increase through all stages of development (Brinster, 1967). Wales \& Whittingham (1968) have found no difference between 1- and 2-cell embryos in their oxidative utilization of lactate or pyruvate; thus the available evidence points either to rate of transport or to rate of glycolysis as the mechanism governing the production of energy from glucose in the embryos.

In the case of malic acid, a difference in permeability between 2- and 8-cell mouse embryos (Wales \& Biggers, 1968) explains why this compound will support development only from the 8-cell stage. The position appears to be quite different for glucose, where similar amounts of glucose carbon accumulate in the cell at the 2- and 8-cell stage during a 30-min incubation. At the same time, the increase in the accumulation of substrate carbon with time was far greater for 8- than 2-cell mouse embryos, indicating that differences exist between 2- and 8-cell mouse embryos in their metabolism of glucose. However, it is not clear if it is the greater accumulation of metabolic products in 8-cell 
embryos or the greater oxidative utilization of glucose by 8- as compared to 2cell embryos (Brinster, 1967) that is responsible for the ability of glucose to maintain development only after the third cell division.

Incubation of the embryos in glucose at the specific activity used resulted in the accumulation of approximately 3 d.p.m./embryo. At such a low level of radio-activity, it was impossible to make even a preliminary fractionation of the substrate carbon accumulated within the cell. Thus the nature of the accumulated products is a matter for debate. No doubt some of the carbon accumulates as the parent substrate. At the same time, some will have entered the carbon pools of the embryo and the net accumulation of isotope will depend on the size and number of these pools and on the rates of reaction repleting and depleting them. Brinster (1967) has indicated that the pentose shunt is operative in mouse embryos at this stage of development, and thus some of the carbon accumulated may arise from synthetic reactions involving this pathway. In addition, Wales \& Whittingham (1968) have found that there is intracellular accumulation of metabolic products following decarboxylation of pyruvate or lactate in the mouse embryo.

The mechanism of transfer of monosaccharides across membranes differs from tissue to tissue. Glucose uptake has been described as active transport in the isolated intestine of the guinea-pig (Riklis, Haber \& Quastel, 1958) and in suspensions of isolated rat intestinal epithelial cells (Stern \& Jensen 1966), but in erythrocytes and muscle has been explained on the basis of an exchange diffusion (Mawe \& Hempling, 1965; Park, Reinwein, Henderson, Cadenas \& Morgan, 1959) involving a membrane carrier but lacking an energy-consuming link. In embryos, elucidation of the mechanism of transport is made difficult because few cells are able to be harvested for study and as mentioned above it was impossible to identify what portion of the intracellular carbon accumulating is the parent substrate. However, a very substantial increase in the specific activity of the substrate may make it possible to recover sufficient isotope to allow identification of the materials accumulated in the embryo and thus to determine if an active transport system exists in embryos for the movement of glucose across the cell membrane. At the same time, the virtual absence of substrate in embryos incubated at $5^{\circ} \mathrm{C}$ indicates that little, if any, of the substrate enters the cell by diffusion.

Galactose, the naturally occurring isomer of glucose, behaves as a nonutilizable substance in most animal tissues (see Levine \& Goldstein, 1955) and has been used as an indicator of hexose transport in spermatozoa (Flipse, 1962). The competition between glucose and galactose in embryos is similar to that reported in guinea-pig intestine (Riklis, Haber \& Quastel, 1958), tissue culture cells (Rickenberg \& Maio, 1960) and rabbit kidney cortex (Krane \& Crane, 1959). However, the finding that mouse embryos utilize galactose to some extent makes it impossible at the present stage of our knowledge to differentiate between competition for uptake as is found in other tissues and competition for entry of metabolic products into the common carbon pools.

ACKNOWLEDGMENTS

This work was supported by grants from the Population Council and the 
National Science Foundation (GB 4465). One of the authors (R.G.W.) is indebted to the Population Council and the Australian Wool Board for financial assistance while on sabbatical leave from the University of Sydney.

\section{REFERENCES}

BRINSTER, R. L. (1963) A method for in vitro cultivation of mouse ova from two-cell to blastocyst. Expl Cell Res. 32, 205.

BRINSTER, R. L. (1965a) Studies on the development of mouse embryos in vitro. II. The effect of energy source. F. exp. Zool. 158, 59.

BRINSTER, R. L. (1965b) Lactic dehydrogenase activity in the preimplanted mouse embryo. Biochim. biophys. Acta, 110, 439.

BRINSTER, R. L. (1967) Carbon dioxide production from glucose by the preimplantation mouse embryo. Expl Cell Res. 47, 271.

Brinster, R. L. \& Thomson, J. L. (1966) Development of eight-cell mouse embryos in vitro. Expl Cell Res. 42, 308.

FLIPSE, R. J. (1962) Metabolism of bovine semen. XII. Galactose as an indicator of hexose transport by bovine spermatozoa. 7. Dairy Sci. 45, 1083.

KRANE, S. M. \& CRANE, R. K. (1959) The accumulation of D-galactose against a concentration gradient by slices of rabbit kidney cortex. F. biol. Chem. 234, 211.

Levine, R. \& Goldstein, M. S. (1955) On the mechanism of action of insulin. Recent Prog. Horm. Res. 11, 343.

Lewis, W. H. \& Wright, E. S. (1935) On the early development of the mouse egg. Contrib. Embryol. $25,113$.

Mawe, R. G. \& Hempling, H. G. (1965) The exchange of $\mathrm{C}^{14}$ glucose across the membrane of the human erythrocyte. F. cell. comp. Physiol. 66, 95.

Park, C. R., Reinwein, D., Henderson, M. J., Cadenas, E. \& Morgan, H. E. (1959) The action of insulin on the transport of glucose through cell membranes. Am. F. Med. 26, 674.

Rickenserg, H. V. \& MAio, J. J. (1960) The transport of galactose by mammalian tissue culture cells. In: Membrane Transport and Metabolism, p. 409. Eds. A. Kleinzeller and A. Kotyk. Academic Press, Londion.

Riklis, E., HABER, B. \& Quastel, J. H. (1958) Absorption of mixtures of sugars by isolated surviving guinea pig intestine. Can. F. Biochem. Physiol. 36, 373.

Stern, B. K. \& Jensen, W. E. (1966) Active transport of glucose by suspensions of isolated rat intestinal epithelial cells. Nature, Lond. 209, 5025.

Wales, R. G. \& BigGers, J. D. (1968) The permeability of two- and eight-cell mouse embryos to L-malic acid. F. Reprod. Fert. 15, 103.

Wales, R. G. \& Whitringham, D. G. (1967) A comparison of the uptake and utilization of lactate and pyruvate by one- and two-cell mouse embryos. Biochim. biophys. Acta, 148, 703. 